Research Article - Araştırma Makalesi

\title{
Coronavirus Risk Assessment and Occupational Health and Safety Practices in Workplaces During Normalization Process
}

\section{Normalleşme Sürecinde İsyyerlerinde Koronavirüs Risk Değerlendirmesi ve İs Sağlı̆̆ı ve Güvenliği Uygulamaları}

\author{
Fatma DEMIRCAN YILDIRIM * \\ (i) 0000-0002-9891-696X
}

Sosyal Güvenlik Dergisi / Journal of Social Security

Cilt: 11 Say1: 1 Y1l: 2021 / Volume: 11 Issue: 1 Year: 2021

Sayfa Aralı̆̆1: 215-226 / Pages:215-226

DOI: $10.32331 /$ sgd.952588

\begin{abstract}
The ongoing COVID-19 outbreak has unprecedented effects worldwide and the extent of infection, illness, and fatalities have forced governments to take more stringent measures. This study aims to identify the risk factors to stop the spread of the virus, develop preliminary plans, and determine applicable measures in workplaces, in summary, to determine new normals in workplaces in the context of the Corona virus challange, utilizing lessons learned from the past pandemics. The United States (US) Centers for Disease Control and Prevention (CDC), the Occupational Safety and Health Administration (OSHA) sources, and Google Scholar, PubMed, Scopus and Web of Science databases were reviewed comprehensively to identify transmission methods, protection methods and risk factors. "Anticipate, Recognize, Evaluate, Control, Confirm (ARECC)", an industrial hygiene decision making method, was used to manage the risk of pathogens in workplaces and hierarchy of hazard control method by the US National Institute for Occupational Safety and Health (NIOSH) was implemented to determine measures. This study identifies hazards, assesses risks, and suggests control measures in changing pandemic conditions with a systematic approach, and presents the suitable ways minimizing the risk to prevent new waves for the pandemics.
\end{abstract}

Anahtar Sözcükler: ARECC, COVID-19 pandemic, normalization process in pandemic, occupational health and safety in pandemic conditions, risk assessment

\section{ÖZ}

Devam eden COVID-19 salgınının, dünya çapında benzeri görülmemiş sonuçları olmuş ve enfeksiyon, hastalık ve ölümlerin boyutu hükümetleri daha katı önlemler almaya zorlamıştır. $\mathrm{Bu}$ çalışma, normalleşme sürecine girilen bu günlerde geçmiş pandemilerden edinilen tecrübelerden yararlanarak işyerlerinde virüsün yayılmasını durdurmak için risk faktörlerinin tanımlanması, hazırlık planlarının geliştirilmesi, uygulanabilir önlemlerin tespit edilmesi, özetle Corona virüsü mücadelesinde işyerlerinde yeni normalleri belirlemeyi amaçlamaktadır. Birleşik Devletler Hastalık Kontrol ve Korunma Merkezi (CDC), Mesleki Güvenlik ve Sağlık İdaresi (OSHA) kaynakları ile Google Scholar, PubMed, Scopus ve Web of Science veri tabanları bulaşma yöntemleri, koruma yöntemleri ve riski faktörlerini belirlemek için kapsamlı bir şekilde gözden geçirilmiştir. İşyerinde patojenler kaynaklı risklerin yönetilmesi için endüstriyel hijyen karar verme yöntemi olan "Öngör, Tanı, Değerlendir, Kontrol Et, Onayla" (ARECC) yöntemi, önlemlerin olarak belirlenmesi için de Birleşik Devletler Ulusal İş Sağlığ 1 ve Güvenliği Enstitüsü (NIOSH) tarafından hazırlanan tehlike kontrolü hiyerarşisi yöntemi uygulanmıştır. Bu çalışma sistematik bir yaklaşımla değişen pandemi koşullarında tehlikeleri tanımlar, riskleri değerlendirir, kontrol önlemleri önerir ve mevcut ve gelecekteki pandemiler için risk yönetimi kararlarını kolaylaştırma nihai hedefi ile yeni dalgaları önlemek için riski en aza indirmenin en uygun yollarını sunar.

Keywords: ARECC, COVID-19 pandemisi, pandemide normalleşme süreci, pandemi koşullarında iş sağlığ 1 ve güvenliği, risk değerlendirmesi

Önerilen atıf şekli: Demircan Yıldırım, F. (2021). Coronavirus Risk Assessment and Occupational Health and Safety Practices in Workplaces During Normalization Process. Sosyal Güvenlik Dergisi (Journal of Social Security). 11(1). $215-226$

• Geliş Tarihi/Received: 18/03/2021 • Güncelleme Tarihi/Revised: 31/05/2021 • Kabul Tarihi/Accepted: 14/06/2021

* Ph.D., Istanbul Commerce University, Graduate School of Natural and Applied Sciences, Department of Occupational Health and Safety, fatmademircann@hotmail.com 


\section{INTRODUCTION}

The novel coronavirus or the other name Severe Acute Respiratory Syndrome Corona Virus2 (SARS-CoV-2) was first identified in Wuhan, China, in December 2019 among a group of patients that have the same symtoms of viral pneumonia upon visiting the same Huanan seafood market (Zhu et al., 2020: 727), and The World Health Organisation (WHO) has declared COVID-19 outbreak a global pandemic on 12 March 2020. The virus is spreading very rapidly with its new variants and as of March 18, 2021 more than 120 million confirmed cases of COVID-19, including more than 2.7 million deaths, have been reported to WHO.

When the effects of past pandemics are evaluated, it is seen that the Spanish flu pandemic emerged in 1918-1920 caused 39 million deaths in only 43 countries (2\% of the world population), which means 150 million deaths compared to the current world population (Barro et al., 2020: 7); H1N1 influenza pandemic emerged in 2009 caused deaths in the ranges of 123,000 to 203,000 and 105,700 to 395,600 (Fineberg, 2014: 1336). According to a simulation based on the data obtained from the Spanish flu pandemic (Nicholson et al., 2019: 47), it was estimated that approximately 50 and 80 million people would die due to pandemic of similar severity (Murray et al., 2006: 2216). However this estimation has already been exceeded.

Apart from the health consequences, a worldwide pandemic has major effects on economy, travel, tourism, education and social life. Therefore it effects even uninfected people. Containment measures have had, on average, a very large impact on economic activityequivalent to a loss of about 15-22 percent in industrial production (IMF, 2020: 6). Global economic losses of the COVID-19 outbreak are estimated to reach up to $\$ 8.8$ trillion (ADB, 2020: 5).

On the other hand, loosening restrictions without inadequate measures leads worse consequences, and higher community transmission, environmental (Mytton et al., 2012: 1538) and behavioral factors, reduced compliance with non-pharmaceutical preventive measures (Hatchett et al., 2007: 7586), strict measures taken in the first wave (Cao et al., 2009: 2514), changes in the virus (Dorigatti et al., 2013: 13422), more usage of antiviral drugs in the first wave (Mytton et al., 2012: 1537), and combination of these factors can lead other waves. The second wave of H1N1 influenza pandemic in 2009 caused nearly four times as many deaths than the first wave, and similar pattern has been observed in the three previous influenza pandemics in the United Kingdom (UK) (Mytton et al., 2012: 1536). However, one and a half years after the first wave, the H1N1 virus caused a third wave of infection in the UK with a greater burden of severe illness compared with the previous year (Dorigatti et al., 2013: 13422). Additionally the Spanish flu pandemic lasted for two years, spreading in successive waves of infection around the world (Trilla et al., 2020: 668), was not quickly eradicated, and as the scientists seem to expect COVID-19 to be the same (Ali, 2020: e17). SARS-CoV-2 (COVID-19) could not be controlled by symptom-based screening alone, unlike the 2003 SARS-CoV outbreak, and there were not any reported case of transmission before the onset of symptoms (Johansson et al., 2021: 2).

In the context of returning safely to the workplace upon the partial or full reopening, safe workplaces must be provided for employees' health and wellbeing in the new normal. Although there are several frameworks and guidelines issued for managing the risks that may arise in the workplace, these guidelines do not explain risk management steps for COVID19 in detail. This study evaluates decision-making frameworks among with the infection control standards to suggest Covid-19 mitigation measures in workplaces with a systemical approach. 


\section{I- SUBJECT AND METHODS}

Guidelines issued by the United States (US) Centers for Disease Control and Prevention (CDC), WHO, the US Occupational Safety and Health Administration (OSHA), and a comprehensive review of Google Scholar, PubMed, Scopus and Web of Science databases have been reviewed to get information about the symptoms, diagnosis, treatment, transmission routes, protection and risk factors. The data obtained as a result of scanning the specified databases were summarized and interpreted under the relevant headings using descriptive analysis method. Recommendations for other pandemics caused by different pathogens that have the similar mechanisms of transmission were also searched. Moreover, scientific publications of institutions identifiying preventive approaches and clinical assessment of various Personal Protective Equipment (PPE) for the corona virus were searched and analyzed.

\section{II-RESULTS}

Safe workplaces play a key role in protecting the health and safety of employees, as well as spreading the pandemic. Possible relationship of 17 of the first 25 Corona virus cases reported in Singapore with occupational exposure (Koh, 2020: 3) have revealed that workplaces are crucial for both spreading and stopping the disease. On the other hand, with the reopening of businesses to varying degrees depending on the risk of their regions, OHS professionals have had difficulties in assessing and managing risks despite having knowledge of "Anticipation, Recognition, Evaluation, Control, and Confirmation (ARECC)" of the hazards in their workplaces.

Figure 1. OHS Decision Making Tool and risk Assessment Paradigm

(Adapted from: Laszcz-David et al., 2014)

$\begin{aligned} & \text { Anticipate and } \\ & \text { Recognize hazard }\end{aligned}$
Hazard Assessment
Determine all the aspects
of the pathogen:
- epidemiology and
pathogenesis
- orgin and spread
treatment


OSHA and CDC have issued strategies and recommendations for current Covid- 19 pandemic that are derived from hierarchy of hazard controls issued by the US National Institute for Occupational Safety and Health (NIOSH) (NIOSH, 2015; CDC, 2020; OSHA, 2020) and ARECC method based on hazard and exposure assessment through identification of risks (Laszcz-David et al., 2014: 27).

The following sections summarize the essential steps for risk management to transform existing OHS frameworks into the COVID-19 pandemic (See Figure 1). This approach first defines jobs by risk categories, then prioritizes the implementation of preventive measures using the control hierarchy.

\section{A- Hazard Assessment}

COVID-19 is also a major challenge for OHS professionals in workplaces. The virus, called corona virus is the causative agent of the COVID-19 pandemic and workers in many occupations face a high risk of infection. As a general and common approach in risk management, it is essential to assess the hazard of the virus in all aspects, firstly.

COVID-19 is the latest biological hazard that poses threat to socio-economics in addition to its devastating effects on human health worldwide (de Carvalho and Nogueira, 2020: 101765) because of having effects of likely to cause serious or fatal human disease for which preventive or therapeutic interventions are not usually available.

Coronavirus primarily targets the human respiratory system and additionally infection can be causative to neurological, renal, hepatic, gastrointestinal, cardiovascular, endocrine, thromboembolic, and dermatological extrapulmonary effects (Gupta et al., 2020: 1018). The most common symptoms at onset of COVID-19 illness are fever, cough, and fatigue and appear after an incubation time is 2-14 days, approximately 5.2 days (Li et al., 2020: 1203). The infectious period duration was maintained at 10 days, and peak infectiousness was varied between 3 and 7 days (Johanssons et al., 2021: 1). Although, the disease is mild in most people and many people are asymptomatic, elderly people and people with health conditions such as asthma, diabetes, cardiovascular diseases (Rothan and Byrareddy, 2020: 1) and cancer (Liang et al., 2020: 336) etc, are in the risk group. Smoking and obesity increase the risk of severe disease (Khorrami et al., 2020: 6).

Real time-polymerase chain reaction (RT-PCR) and chest computed tomography (CT) are routinely used in diagnosis of the virus (Corman et al., 2020: 23; He et al., 2020: 723). Current treatment options are mainly based on possible pharmacological mechanisms and therapeutic agents, non-well-designed trials and the experience of clinicians. Treatment is supportive and sypmtomatic; while prevention is cruicial. Preventive measures are mainly based on the use of mask, maintaining a social distance of at least 2 metres, and frequent and thorough handwashing (WHO, 2020).

On the other hand development and fair distribution of a vaccine is the only way to get the pandemic under control. As a result of vaccine development studies that have begun in early April 2020, some of them achieved to be authorized for emergency use. Altough the introduction of vaccination in many countries has raised hopes in terms of getting the pandemic under control, the recent news about the mutated variants of the novel coronavirus worries governments and people about the future. On the other hand, WHO is warning that worldwide vaccination is expected to take a long time due to the time required for manufacturing and distribution of millions of doses, uncertaininty about immunity of vaccines and probabilty of having access to vaccine (Mellet and Pepper, 2021: 4). Therefore it is obvious that the world have to continue to live with preventive measures for at least a 
few years due to time required for manufacturing, distrubition, vaccination of society, obscurity about protection duration of the vaccines.

\section{B- Exposure Assessment}

The virus could spread with droplet over 7-8 m and 1-2 $\mathrm{m}$ through coughs or sneezes (Bourouiba, 2020: 1838), and the risk of transmission at $1 \mathrm{~m}$ could be 2-10 times higher than at $2 \mathrm{~m}$ (Jones et al., 2020: 4). Close contact and touching surfaces contaminated by them are the other transmission routes (He et al., 2020: 720). Transmission can occur from both symptomatic and asymptomatic persons before onset of symptoms (Singhal, 2020: 282). Long incubation time before onset of symptoms is the greatest challange to prevent spread. Therefore, preventive measures must be implemented by all people, whether they are infected or not.

While many bacteria and microbacteria can survive for months on the banknotes and coins (Kramer et al., 2006: 2), respiratory tract viruses, such as Coronavirus, can survive on surfaces for a few days, three days on plastic surfaces as well as on stainless steel surface, one day on cardboards, and four hours on copper surfaces (Suman et al., 2020: 386) and many of the workers either have physical contact with directly or indirectly with the mentioned surfaces (Angelakis et al., 2014: 249). There fore sharing equipment plays key role spreading the infectious virus (Kurgat et al., 2019: 484). This makes all surfaces suspicious in terms of the possibility of being corona virus carrier and can cause transmission of the virus only a single contact.

\section{C- Risk Management}

Determination of occupations with high risk is crucial for risk assessment. The risk of exposure to virus depends on several factors: e.g. the work sector; the need for close contact with people known to be or suspected of being infected (Spinazze et al., 2020: 560); OSHA has cateorized occupations into four risk levels from very high to lower and most of the workers in the world will likely fall in the lower or medium risk levels (OSHA, 2020). Workers with the highest risk have been employing in healthcare services, protective services, personal care and services, community and social services, education, training; and employees working across different sectors are exposed to disease or infection at work more than once a month (18.4\%) and once a week (10\%) (Baker et al., 2020: 4).

\section{D- Hierarchy of Hazard Control}

Reducing the risk of transmission of virus based on the implementation of the hierarchy of hazard controls requires a comprehensive strategy, and cooperation of the governments and the related institutions are very important in managing the pandemic process.

Major transmission routes of corona virus are contact and inhalation, therefore transmisson can be stopped by preventing the two factors, virus and worker, from coming together in the workplaces. Elimination of transmission routes, identification and preventing of high contact activities, reduction of viral load, identification of exposure levels and vulnerable workers must be determined by applying hierarchy of hazard controls. This means putting in place the control measures to first eliminate the risk and if this is not possible, minimize worker exposure.

Multiple types of hierarchy of controls has been widely used to manage risks related to biological hazards simultaneously (Sietsema et al. 2019: 126) with a strategy consist of source-pathway-receptor paradigm, respectively (See Figure 2). 
While determining preventive measures, secondary hazards and risks should also be evaluated. These secondary hazards may be respiratory system and skin diseases related to sanitizers and cleaning agents, increase of transmission by touching nose and mouth due to improper use of PPE, or psychological disorders caused by concerns about the health of the person and their family.

Figure 2. The Hierarchy of Hazard Control (Adapted from: NIOSH, 2015).

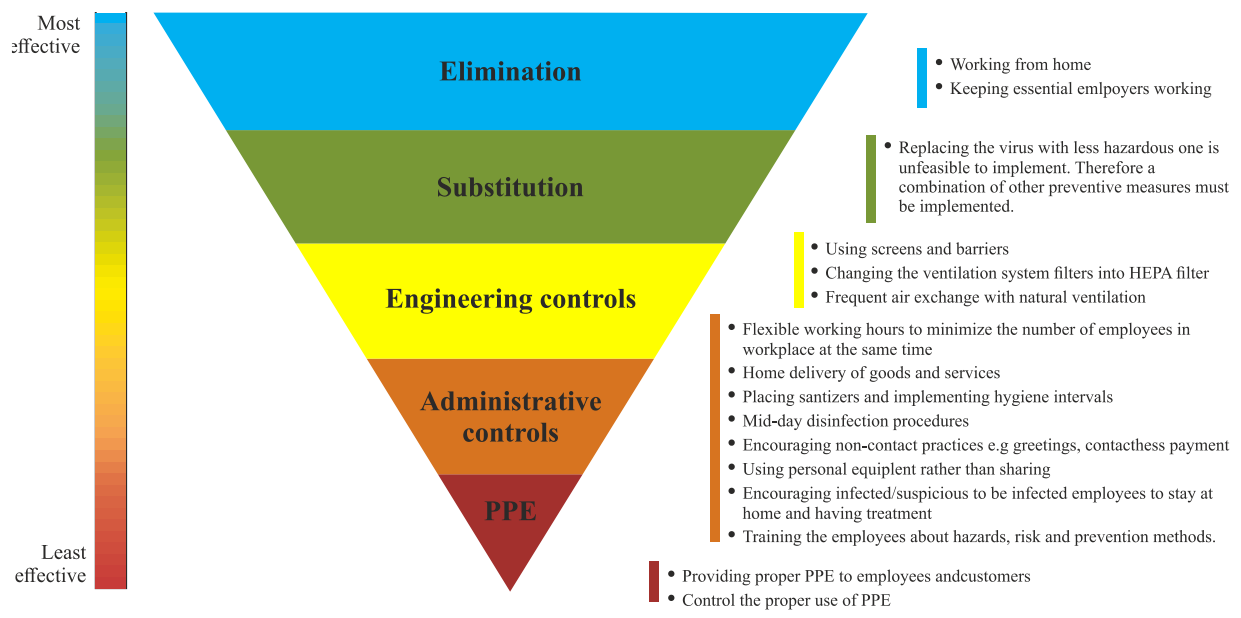

\section{i) Elimination}

Elimination is the best way to mitigate the risks (OSHA, 2003) and based on the principle to change how or where the work is done. Reducing face-to-face contact is the first option to reduce the transmission of the virus. Therefore many companies choose to work from home temporarily or as an alternative working arrangement using technology.

It should be determined whether the occupation is suitable for working from home, firstly. If the occupation is suitable for working from home, the necessary information and communication technology and working conditions must be provided in which the worker can maintain his/her physical and mental well-being.

\section{ii) Substitution}

Substitution is the second option to remove risk and risk is replaced with another risk that is either less likely to occur or less severe in its potential damages. For chemical and biological hazards, substitution requirements are even more stringent (OSHA, 2003). Therefore application of other multiple types of control measures are required to prevent or minimize exposure to the virus (ILO, 2020a).

\section{iii) Engineering Controls}

The International Labour Organisation (ILO) estimates that approximately $18 \%$ of workers have occupations that are suitable for working from home (ILO, 2020b), therefore since elimination and substitution are not feasible for much of the occupations to work remotely, engineering controls must be implemented to reduce the hazard/risk at source without relaying to worker behavior. 
Structural measures like simple screens and barriers provide more protection from COVID19 compared to face-to-face style of work (Semple and Cherrie, 2020: 463). Barrier usage and natural ventilation are common practices for both controlling and preventing the spread of infection at the source and along the path. Impervious barriers can be placed, especially for workers and customers who are not able to keep a two-meter distance from each other. Contactless payment must be encouraged rather than banknotes, coins etc.

Although, the viral particles are too small to be filtered by even the best High Efficiency Particulate Arresting (HEPA) and Minimum Efficiency Reporting Value (MERV) filters, proper filter installation and maintenance can help to reduce the risk of airborne transmission (Dietz et al., 2020: 6). Additionally, higher air exchange rates provides dilution of the virus load.

\section{iv) Administrative Controls}

Administrative and organizational controls limit exposure by limiting work times in contaminated areas or by implementing other "rules" and rely to change of worker behaviour and current condition; the hazard is not actually eliminated or reduced. Therefore they are not a reliable way or sustainable for a long time to reduce exposure.

To combat with Coronavirus, remote work must be first option for those working in sectors or departments that are possible, and especially for those in the risk group. Only essential work must be carried out with minimized number of workers. Scheduling shorter work times with flexible work practices must be encouraged to reduce occupancy in workplace. If close contact is unavoidable, it should be kept as short as possible to reduce viral load. Employees' break times should be arranged to reduce occupancy and virus load. In addition, employees must pay attention to protective measures during break times. Home delivery of goods and services must preferred rather than online services or sales. Greetings like handshakes must be replaced to other noncontact methods in face-to-face contact. Medical examination of all employees must be revised whether they are in risk group.

Work travels must discontinued and face-to-face contact between employees and customers must be minimized by using technologies such as e-mail, websites and teleconferences.

Frequent cleaning of surfaces with proper biocidal cleaning agents (Kampf et al., 2020: 250) and disinfection of hands with alcohol based sanitizers can reduce the transmission of pathogenic agents (Boyce and Pittet, 2002: 17; Arbogast et al., 2018: 232) by 85.4\% (Kurgat et al., 2019: 481). There is a wide range of cleaning agents and sanitizers; and the biocidal material varies from natural materials to synthetic materials and most of them are hazardous for human health (Samara, Badran and Dalibalta; 2020: 496-497). However, mostly used sanitizers are volatile chemicals and the effects are relatively short lived based on ingredient (Jing et al., 2020: 3), therefore the best defense for to stop transmission of virus is to ensure behavior change by washing hands frequently with soap (Berardi et al., 2020: 2). More persistent surface cleaning treatments, nanomaterials such as nano-silver, may be preferred to reduce virus load on the surfaces (Rai et al., 2016: 49) and nanoparticle treated air filters (Joe et al., 2016: 551) for airborne virus load.

Sharing equipment and tools in the working environment must be avoided as much as possible, and all employees must use the areas and items identified for themselves. Equipments with hands-free option must be preferred. Critical locations with high risk must be disinfected frequently to reduce pathogen contamination. Hands must be disinfected after any potentially suspicious contact. However, as much as these products keep people clean and prevent transmission of the virus, these solutions include chemical agents and excessive 
use of these can be harmful both for health and environment (Casey et al., 2020: 1134), therefore frequent and thorough hand washing with soap can be identified as the best way for disinfection.

Infected/suspicious to be infected employees must be encouraged to stay at home and having treatment. The employee should not be asked to return to work without making sure that the disease is treated.

Measures maintaining physical distancing and providing hygiene must be implemented in workplaces, both for employees and customers. Implementation of the hygiene rules with providing hand sanitizers etc significantly reduces the viral load on hands (Hulkower et al., 2011). Hygiene rules and physical distance can be applied relatively easily without high cost but require workers to change their behaviours and habits and may be difficult to sustain.

Since behavior change is difficult and requires sustained motivation and support, nevertheless most efforts to change behaviours have had limited success (Kelly and Barker, 2016: 110). Therefore training is crucial for employees' support to safety plan including instructions about hazards of COVID-19, transmission routes, prevention, hygiene rules, physical distancing, and PPE.

It must not be ignored that customers are also sources of hazard, and as risky as employees. The occupancy of workplace to ensure adequate two meter spacing between individuals must be set by placing tape on the floor to help customers determine how far to stand from another people.

Additionally, in order to ensure that employees and customers are aware of the pandemic safety plan, warning boards must be placed where people can easily notice. Perhaps social media can be used to inform people about the steps that workplace is trying to protect public health.

\section{v) Personal Protective Equipments}

As WHO and other institutions have recommended, wearing proper mask or PPE is one of the major defence to coronavirus (WHO, 2020). Surgical mask usage could reduce the risk of being infected and N95 and FFP2 masks provide a certain level of protection against viruses (Chu et al., 2020: 1979). However, using PPE must not take the place of primary prevention interventions, which are elimination, substitution, engineering controls, administrative controls and hygiene rules. Employers must provide proper PPE such as respirators, mask, face shield, gloves, gowns etc to ensure safe workplaces for employees.

Although the use of a mask prevents touching the face, nose and mouth, there is also a risk of increased contact due to discomfort and irritation. Glove usage can encourage more inattentive and unsafe behavior, similarly. If PPE is used, proper disposal is essential to avoid transmission in different routes and for protecting environment.

\section{CONCLUSION}

Corona virus is a biological hazard and no one knows when pandemic will end. Therefore we all have to learn to live with pandemic by transforming our behaviors, habits, houses, schools and workplaces according to the "new normals" based on reducing the infection risk. The major of the society is not yet infected and OHS measures to be taken at workplaces will prevent the occurrence of next waves of the pandemic and ensures the increase of cases in acceptable limits. 
In order to minimize the health risk of coronavirus in workplaces, OHS professionals should make appropriate recommendations for all employees. Although the lack of knowledge about coronavirus and experience in managing pandemic, risk assessment process must be based on appropriate risk management steps and hierarchy of hazard control to reduce transmission and virus load in the workplace. In order to minimize the effects of both current and future outbreaks, risk management process must be designed on a multidisciplinary approach that combines the current data with psychosocial and community factors. This study provides a guidance for risk management studies that consist of hygiene, social distancing and PPE for workplaces at different risk levels, and is benefical for regulatory institutions, researches and OHS professionals.

\section{Declarations}

The author has no financial or proprietary interests in any material discussed in this article.

Funding No funding was received to assist in the preparation of this manuscript.

Conflicts of interest/Competing interests The author declares that there is no conflict of interest.

\section{Availability of data and material Not applicable}

\section{Code availability Not applicable}

Author's contribution: The author confirms sole responsibility for the following: study conception and design, data collection, analysis and interpretation of results, and manuscript preparation.

\section{References}

Ali, I. (2020). COVID-19: Are we Ready for the Second Wave? Disaster Medicine and Public Health Preparedness. 6. 18. doi: 10.1017/dmp. 2020.149

Angelakis, E., Azhar, E. I., Bibi, F., Yasir, M., Al-Ghamdi, A. K., Ashshi, A. M., et al. (2014). Paper Money and Coins as Potential Vectors of Transmissible Disease. Future Microbiology. 9.2. 249-261. doi: 10.2217/FMB.13.161

Arbogast, J. W., Moore-Schiltz, L., Jarvis, W.R., Harpster-Hagen, A., Hughes, J., and Parker, A. (2016). Impact of a Comprehensive Workplace Hand Hygiene Program on Employer Health Care Insurance Claims and Costs, Absenteeism, and Employee Perceptions and Practices. Journal of occupational and Environmental Medicine. 58.6. 231-240. doi: 10.1097/JOM .0000000000000738

Asian Development Bank (2020). Updated Assessment of the Potential Economic Impact of COVID-19. $A D B$ Briefs 133. 1-16. doi: 10. 22617/BRF200144-2.
Baker, M. G., Peckham, T. K. and Seixas, N. S. (2020). Estimating the Burden of United States Workers Exposed to Infection or Disease: A Key Factor in Containing Risk of COVID-19 Infection. PloS One. 15.4. e0232452. doi: 10.1371/journal.pone.0232452

Barro, R. J., Ursúa, J. F. and Weng, J. (2020). The Coronavirus and the Great Influenza Pandemic: Lessons From the Spanish Flu” For the Coronavirus's Potential Effects on Mortality and Economic Activity. National Bureau of Economic Research. Working Paper 26866. 1.27. doi: $10.3386 /$ w26866

Berardi, A., Perinelli, D. R., Merchant, H. A., Bisharat, L., Basheti, I. A., Bonacucina, G., ... \& Palmieri, G. F. (2020). Hand Sanitisers Amid COVID-19: A Critical Review of AlcoholBased Products on the Market and Formulation Approaches to Respond to Increasing Demand. International Journal of Pharmaceutics. 119431. doi: 10.1016/j.ijpharm.2020.119431 
Bourouiba, L. (2020). Turbulent Gas Clouds and Respiratory Pathogen Emissions: Potential Implications For Reducing Transmission of COVID-19. Jama. 323.18. 1837-1838. doi:10.1001/jama.2020.4756

Boyce, J. M. and Pittet, D. (2002). Guideline for Hand Hygiene in Health-Care Settings: Recommendations of the Healthcare Infection Control Practices Advisory Committee and the HICPAC/SHEA/APIC/IDSA Hand Hygiene Task Force. American Journal of Infection Control. 30.8. 1.46. doi: 10.1067/mic.2002. 130391

Cao, B., Li, X. W., Mao, Y., Wang, J., Lu, H. Z., Chen, Y.S., et al. (2009). Clinical Features of the Initial Cases of 2009 Pandemic Influenza a (H1N1) Virus Infection in China. New England Journal of Medicine. 361.26. 2507-2517. doi: 10.1056/NEJMoa0906612

Casey, M. L., Hawley, B., Edwards, N., CoxGanser, J. M. and Cummings, K. J. (2017). Health Problems and Disinfectant Product Exposure Among Staff at a Large Multispecialty Hospital. American Journal of Infection Control. 45.10. 1133-1138. doi: 10.1016/j.ajic.2017.04. 003

Centers for Disease Control and Prevention (2020). Coronavirus Disease 2019 (COVID-19). Interim Guidance for Businesses \& Employers: Plan Prepare and Respond to Coronavirus Disease 2019. [https://www.cdc.gov /coronavirus/2019-ncov/community/guidancebusiness-response.html]. (Accessed: 18 August 2020).

Chu, D. K., Akl, E. A., Duda, S., Solo, K., Yaacoub, S., Schünemann, H. J., et al. (2020). Physical Distancing, Fface Nasks and Eye Protection to Prevent Person-to-Person Transmission of SARS-CoV-2 and COVID-19: a Systematic Review and Meta-Analysis. The Lancet. 395.10242. 1973-1987. doi: 10. 1016/S0140-6736(20)31142-9

Corman, V. M., Landt, O., Kaiser, M., Molenkamp, R., Meijer, A., Chu, D. K., et al. (2020). Detection of 2019 Novel Coronavirus (2019-nCoV) By Real-Time RT-PCR. Eurosurveillance. 25.3. 2000045. doi: 10.2807/1560-7917.ES.2020.25.3.2000045

De Carvalho, L. and Nogueira, M. S. (2020). Optical Techniques For Fast Screening Towards Prevention of the Coronavirus COVID19 Outbreak. Photodiagnosis and Photodynamic Therapy. 30. 101765. doi: 10.1016/j.pdpdt. 2020.101765
Dietz, L., Horve, P. F., Coil, D. A., Fretz, M., Eisen, J. A. and Van Den Wymelenberg, K. (2020). 2019 Novel Coronavirus (COVID-19) Pandemic: Built Environment Considerations to Reduce Transmission. MSystem 5.2. e00245-20. doi: 10.1128/mSystems.00245-20

Dorigatti, I., Cauchemez, S. and Ferguson, N. M. (2013). Increased Transmissibility Explains the Third Wave of Infection By the 2009 H1N1 Pandemic Virus in England. Proceedings of the National Academy of Sciences. 110.33. 1342213427. doi: 10.1073/pnas.1303117110

Fineberg, H. V. (2014). Pandemic Preparedness and Response-Lessons From the H1N1 Influenza of 2009. New England Journal of Medicine. 370.14. 1335-1342. doi: 10.1056/ NEJMra1208802

Gupta, A., Madhavan, M. V., Sehgal, K., Nair, N., Mahajan, S., et al. (2020). Extrapulmonary Manifestations of COVID-19. Nature Medicine. 26. 1017-1032. doi: 10.1038/s41591-020-09683

Hatchett, R. J., Mecher, C. E. and Lipsitch, M. (2007). Public Health Interventions and Epidemic Intensity During the 1918 Influenza Pandemic. Proceedings of the National Academy of Sciences. 104.18. 7582-7587. doi: 10.1073pnas.0610941104

He, F., Deng, Y., and Li, W. (2020). Coronavirus Disease 2019: What We Know? Journal of Medical Virology. 92. 719-725. doi: 10.1002/ jmv.25766

Hulkower, R. L., Casanova, L. M., Rutala, W. A., Weber, D. J. and Sobsey, M. D. (2011). Inactivation of Surrogate Coronaviruses on Hard Surfaces by Health Care Germicides. American Journal of Infection Control. 39.5. 401-407. doi: 10.1016/j.ajic.2010.08.011

International Labor Organisation (2020a). A Safe and Healthy Return to Work During the COVID-19 Pandemic.[https://www.ilo.org/ wcmsp5/groups/public/---ed_protect/---protrav /--- safework / documents / briefingnote / wcms_ 745549.pdf]. (Accessed: 12 October 2020).

International Labor Organisation (2020b). An Employers' Guide on Working From Home in Response to the Outbreak of COVID-19. [https://www.ilo.org/wcmsp5/groups/public / --ed_dialogue/---act_emp/documents/publication/ wcms_745024.pdf]. (Accessed: 12 October 2020). 
International Monetary Fond (2020). The Economic Effects of COVID-19 Containment Measures. IMF Working Paper WP/20/158. [https://www.imf.org/ /media/Files/Publication s / WP / 2020 / English / wpiea 2020158 - print -pdf.ashx]. (Accessed: 01 October 2020).

Jing, J. L. J., Pei Yi, T., Bose, R. J., McCarthy, J. R., Tharmalingam, N. and Madheswaran, T. (2020). Hand sanitizers: A Review On Formulation Aspects, Adverse Effects and Regulations. International Journal of Environmental Research and Public Health. 17.9. 3326. doi: $10.3390 /$ ijerph 17093326

Joe, Y. H., Park, D. H. and Hwang, J. (2016). Evaluation of Ag Nanoparticle Coated Air Filter Against Aerosolized Virus: Anti-Viral Efficiency With Dust Loading. Journal of Hazardous Materials. 301. 547-553. doi: 10.1016/j.jhazmat.2015.09.017

Johansson, M. A., Quandelacy, T. M., Kada, S., Prasad, P. V., Steele, M., Brooks, J. T., et al. (2021). SARS-CoV-2 Transmission From People Without COVID-19 Symptoms. JAMA Network Open. 4.1. e2035057. doi: 10.1001/jamanetworkopen.2020.35057. doi:10.1001/jamanetworkopen.2020.35057

Jones, N. R., Qureshi, Z. U., Temple, R. J., Larwood, J. P., Greenhalgh, T. and Bourouiba, L. (2020). Two Metres or One: What is the Evidence for Physical Distancing in COVID-19? BMJ. 370. m3223. doi: 10.1136/bmj.m3223

Kampf, G., Todt, D., Pfaender, S. and Steinmann, E. (2020). Persistence of Coronaviruses on Inanimate Surfaces and Their Inactivation With Biocidal Agents. Journal of Hospital Infection. 104.3. 246-251. doi: 10.1016/j.jhin.2020.01.022

Kelly, M. P. and Barker, M. (2016). Why is Changing Health-Related Behaviour So Difficult? Public Health. 136. 109-116. doi: 10.1016/j.puhe.2016.03.030

Khorrami, Z., Nili, S., Sharifi, H., Eybpoosh, S. and Shokoohi, M. (2020). Association of Cigarette Smoking, Obesity, and Underlying Medical Conditions With COVID-19 Hospitalization and Mortality in Iran: A Nationwide Retrospective Ecological Study. Medical Journal of the Islamic Republic of Iran. 34. 133. doi: 10.34171/mjiri.34.133
Koh, D. (2020). Occupational Risks for COVID19 Infection. Occupational Medicine. 70.1. 3-5. doi: 10.1093/occmed/kqaa036

Kramer, A., Schwebke, I., and Kampf, G. (2006). How Long do Nosocomial Pathogens Persist on Inanimate Surfaces? A Systematic Review. BMC Infectious Disease. 6.1. 130. doi: 10.1186/1471-2334-6-130

Kurgat, E. K., Sexton, J. D., Garavito, F., Reynolds, A., Contreras, R. D., Gerba, C. P., et al. (2019). Impact of a Hygiene Intervention on Virus Spread in an Office Building. International Journal of Hygiene and Environmental Health. 222.3. 479-485. doi: 10.1016/j.ijheh.2019.01.001

Laszcz-Davis, C., Maier, A., and Perkins, J. (2014). The Hierarchy of OELs: A new Organizing Principle For Occupational Risk Assessment. The Synergist. 26-30.

Li, Q., Guan, X., Wu, P., Wang, X., Zhou, L., Tong, Y., et al. (2020). Early transmission Dynamics in Wuhan, China of Novel Coronavirus-Infected Pneumonia. New England Journal of Medicine. 382.13. 1199-1207. doi: 10.1056/NEJMoa2001316

Liang, W., Guan, W., Chen, R., Wang, W., Li, J., Xu, K., et al. (2020). Cancer pPatients in SARS-CoV-2 Infection: A Nationwide Analysis in China. The Lancet Oncology. 21.3. 335-337. doi: 10.1016/S1470-2045(20)30096-6

Mellet, J. and Pepper, M. S. (2021). A COVID19 Vaccine: Big Strides Come with Big Challenges. Vaccines. 9.1. 39. doi: 10.3390/vaccines9010039

Murray, C. J., Lopez, A. D., Chin, B., Feehan, D., and Hill, K. H. (2006). Estimation of Potential Global Pandemic Influenza Mortality on the Basis of Vital Registry Data From the 1918-20 Pandemic: A quantitative Analysis. The Lancet. 368.9554. 2211-2218. doi: 10.1016/S0140-6736(06)69895-4.

Mytton, O. T., Rutter, P. D., Mak, M., Stanton, E. A. I., Sachedina, N., and Donaldson, L. J. (2012). Mortality due to pandemic (H1N1) 2009 influenza in England: a comparison of the first and second waves. Epidemiology \& Infection, 140(9), 1533-1541. doi: 10.1017/ S0950268811001968 
National Institute for Occupational Health and Safety (2015). Hierarchy of Controls. [https://www.cdc.gov/niosh/topics/hierarchy/de fault.html]. (Accessed: 10 October 2020).

Nicholson, A., Shah, C. M., Ogawa, V. A., and National Academies of Sciences, Engineering, and Medicine. (2019, May). Is the World Ready to Respond to the Next Influenza Pandemic? In Exploring Lessons Learned from a Century of Outbreaks: Readiness for 2030: Proceedings of a Workshop. National Academies Press (US). doi:10.17226/25391

Occupational Safety and Health Administration (2003). Elimination and Substitution of Dangerous Substances. [https://osha.europa.eu/ en/publications/factsheets/34]. (Accessed: 12 October 2020).

Occupational Safety and Health Administration (2020). Guidance on Preparing Workplaces for COVID-19. OSHA 3990-03 2020. [https:// nmcdn.io/e186d21f8c7946a19faed23c3da2f0da /9daed2ecce2a4df2845caa12db947e3d/files/OS HA3993.pdf]. (Accessed: 12 October 2020).

Rai, M., Deshmukh, S. D., Ingle, A. P., Gupta, I. R., Galdiero, M., and Galdiero, S. (2016). Metal Nanoparticles: The Protective Nanoshield Against Virus Infection. Critical Reviews in Microbiology. 42.1. 46-56. doi: 10.3109/ 1040841X.2013.879849

Rothan, H. A. and Byrareddy, S. N. (2020). The Epidemiology and Pathogenesis of Coronavirus Disease (COVID-19) Outbreak. Journal of Autoimmunity. 109. 102433. doi: 10.1016/ j.jaut.2020.102433

Samara, F., Badran, R., and Dalibalta, S. (2020). Are Disinfectants for the Prevention and Control of COVID-19 Safe? Health Security. 18.6. 496498. doi: 10.1089/hs.2020.0104

Semple, S. and Cherrie, J. W. (2020). COVID19: Protecting Worker Health. Annals of Work Exposures and Health. 64.5. 461-464. doi: 10.1093/annweh/wxaa033

Sietsema, M., Radonovich, L., Hearl, F. J., Fisher, E. M., Brosseau, L. M., Shaffer, R. E., and Koonin, L. M. (2019). A Control Banding Framework for Protecting the US Workforce from Aerosol Transmissible Infectious Disease Outbreaks With High Public Health Consequences. Health Security. 17.2. 124-132. doi: 10.1089/hs.2018.0103
Singhal, T. (2020). A Review of Coronavirus Disease-2019 (COVID-19). The Indian Journal of Pediatrics. 87.4. 281-286. doi: 10.1007/s12098-020-03263-6

Spinazzè, A., Cattaneo, A., and Cavallo, D. M. (2020). COVID-19 outbreak in Italy: Protecting Worker health and the response of the Italian Industrial Hygienists Association. Annals of Work Exposures and Health. 64.6. 559-564. doi: 10.1093/annweh/wxaa044

Suman, R., Javaid, M., Haleem, A., Vaishya, R., Bahl, S., and Nandan, D. (2020). Sustainability of Coronavirus on Different Surfaces. Journal of Clinical and Experimental Hepatology. 10.4. 386.390. doi: 10.1016/j.jceh.2020.04.020

Trilla, A., Trilla, G., and Daer, C. (2008). The 1918 "Spanish Flu" in Spain. Clinical Infectious Diseases. 47.5. 668-673. doi: 10.1086/590567

World Health Organisation (2020). Basic Protective Measures Against the New Coronavirus. [https://www.who.int/emergencies /diseases/novel-coronavirus-2019/advice-forpublic]. (Accessed: 01 June 2020).

Zhu, N., Zhang, D., Wang, W., Li, X., Yang, B., Song, J., et al. (2020). A Novel Coronavirus From Patients With Pneumonia in China. 2019. New England Journal of Medicine. 382. 727733. doi: 10.1056/NEJMoa2001017 